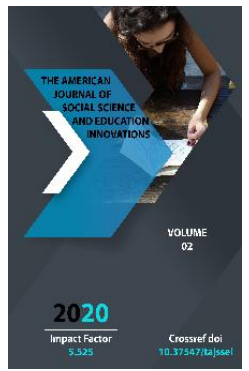

Journal

Website: http://usajournalshub.c om/index,php/tajssei

Copyright: Original content from this work may be used under the terms of the creative commons attributes 4.0 licence.

\section{An Investigation Of Element Achieve Intellectual Accomplishment Of Proposed Educator}

\author{
Dr. Afzal Nazimuddin \\ Organization Of Education And Research University Of The Punjab Lahore, Pakistan \\ Ghulam Ali khan \\ College of Sargodha, Pakistan
}

\title{
ABSTRACT
}

The paper attempted to explain elements impacting the scholarly accomplishment of planned educators concentrating on various instructor training programs. The administration has zeroed in on the improvement in the nature of training particularly after the quantitative development of enrolment rates at all degrees of instruction. As one of the models of the nature of training, imminent educators' scholarly accomplishment was researched in the paper, since scholastic accomplishment is frequently referred to as an institutional viability marker by administrators, instructors, understudies, and their folks. The investigation was completed on an example of 200 understudies of 9 branches of the Institute of Education and Research, University of the Punjab, Pakistan. The example was haphazardly chosen and 22 understudies of the fourth semester from every division were taken. A Combined Grade Point Average (CGPA) of understudies was additionally taken. Data was gathered through a survey. The consequence of the examination investigation demonstrated that parental inclusion, instructor showing style, financial status, peer pressure, and motivation were affecting under investigation's accomplishment.

\section{KEYWORDS}

Element, Effect, Intellectual, Accomplishment.

\section{INTRODUCTION}

Instruction has been viewed as a key factor for public improvement by the Pakistani government. Through their solid activity,
Teacher training has been organized. It is viewed as vital in light of the fact that instructors with solid intellectual aptitudes 
can show better outcomes at all degrees of training in Pakistan. Thusly the arrangement of planned educators is critical as the nation's future is in their grasp. Distinguishing elements that impact understudies' learning and along these lines accomplishment keeps on being a significant target of educators at all levels. Different elements influence under investigation accomplishment at advanced education level like individual certainty and sentiment of fitness in learning; confident however reasonable projection into the future word-related jobs and social jobs; enthusiastic solidness; inconsistent inclination towards contemplation; relative freedom from instructors and an inferred acknowledgment of the curricular and work requests emerging inside the structure of educational cost. Selfefficacy has been distinguished as a positive indicator of scholastic execution.

There are numerous components those impact the presentation of understudies however for this examination; understudies' scholarly accomplishment was investigated regarding five sorts of elementi.e. Parental contribution, peer pressure, instructors' showing style, financial status, and inspiration. These components were chosen dependent on the survey of past exploration. Sakigawa, (2003) examined understudies' scholastic accomplishment regarding three sorts of elements, family element, singular element, and school element. The outcome indicated that three components directly affected understudies' self-revealing of scholarly accomplishment. The most grounded factor is understudies' capability in Vietnamese, and the following is guardians' enthusiasm for youngster's investigation trailed by the presence of dear companions in school. For this examination investigation following elements was dissected:
- Parents' Involvement and backing

- Peer Pressure

- Teacher Teaching Style

- Scio-monetary Status

- Motivation

\section{UNDERSTUDIES' INSPIRATION}

Understudies' inspiration and scholastic accomplishment are legitimately influenced by their associations with their educators and by the sort of explanations they get from them. Understudies who have positive associations with their instructors and get more worth remarks than hope remarks to show more elevated levels of inspiration and scholarly accomplishment. one instructional variable, verbal applause, has frequently been distinguished as a significant go-between in the upgrade of understudies' inspiration in the investigation hall. Then again, Good (1987) revealed that more established understudies disregarded the acclaim that they saw as invalid and deciphered commendation given for simple undertakings as a sign that the educator had low desires for them.

\section{DESTINATIONS OF THE INVESTIGATION}

- To discover the impact of components on various branches of the foundation of instruction and examination.

- To discover the impact of parental association, Peer weight, and educator showing style on under investigation scholastic accomplishment. 
- To discover the impact of financial status and inspiration status on under investigation scholastic accomplishment.

\section{EXPLORATION INSTRUMENT}

The survey was utilized to gather the information which was comprised of 25 explanations on a five-point Liker type scale. The poll depended on five classes (element) for example Guardians' contribution, instructors' showing style, peer pressure, financial status, and inspiration. The information was gathered from the understudies of the Institute of Education and Research, Punjab University.

\section{CONCLUSION}

A decent friend bunch is important to accomplish great outcomes. In the event that the friend bunch is scholastically brilliant, the student would likewise work more enthusiastically to accomplish passing marks so as to expand his/her performance. The teaching abilities of the educator can likewise influence youngster's pace of accomplishment. As seeing, the benevolent condition between an educator and under investigation constrains the youngster to invest more energy for his own pleasure instead of a severely trained one.

A decent showing condition and a solid connection with the instructor, builds the ability of under investigation. Along these lines encouraging style would be present-day and flexible to make youngsters work to their best of capacities. The manner in which the instructor manages an under investigation builds up the enthusiasm for a particular subject and this intrigue legitimately influences grades. The current investigation tried to inspect the impact of variables on student intellectual accomplishment of Institute of Education and Research. It was inferred that there was no noteworthy impact on parental inclusion, peer pressure, financial status and inspiration on under investigation scholarly accomplishment aside from the educators' instructing style. Also, there was no noteworthy impact of components on various divisions of the Institute of Education and Research.

\section{REFERENCES}

1. Hallinan, M.T, (1996) Effects on investigation hall intrigue. Instructive Psychologist, 38 (5), 96-108.

2. Makunde, A.P.(1997) Displaying TIMSS Data in a European Comparative Perspective: Exploring Influencing Element on Accomplishment in Mathematics in Grade 8. Instructive Research and Evaluation, 8 (3), 147 - 159.

3. Robson, C. (1996). Changes in School Characteristics Coincident with Changes in Student Accomplishment.

4. Walliman, N, and Buckler's (1996). Transforming scholastics into educators. In S. Rowland et al. Instructing in Higher Education, 6 (8), 312-16.

5. Chaudhry, A. H. (2006). Impact of Guidance Services on Investigation Attitudes, Investigation Habits, and Intellectual Accomplishment of Secondary School Students. Release of Education and Research 28, (1), 35-45. 